\title{
PRESS RELEASES
}

\section{Government's report on the 20II-20I5 term of office - We write at length, because there is "no time" to be concise}

\author{
Anto BAJO, PHD., Institute of Public Finance, Zagreb \\ MARKO PRIMORAC, PHD., Faculty of Economics and Business, Zagreb
}

\begin{abstract}
At its last, 272nd regular session on January I4, 20I6, the Government accepted a Report on the Work of the Government of the Republic of Groatia and on the Outstanding Liabilities Assumed During the Term of Office of the Prime Minister Zoran Milanović. Despite its 2,259 ${ }^{1}$ pages, the Report lacks key information on the Government's financial activities and their fiscal and economic consequences. Moreover, it is poorly laid out and uninformative and can therefore not be used as a basis to assess the Government's work.
\end{abstract}

\begin{abstract}
A pro forma report. The Report has been prepared to meet the formal requirement laid down in Article 2, paragraph (2) of the Act on the Power Transfer Procedure (OG 94/O4, I7/O7, 9I/IO and 22/I3) which stipulates that the Government whose term of office has expired shall inform in detail the Government that takes the office of the status and problems in the performance of activities within the authority of the Government, and Article 3 of that Act, stipulating the obligation to submit reports on outstanding liabilities assumed as at the handover date.
\end{abstract}

Inadequate content. The Report is an overview of the work of 43 public bodies (20 ministries and 23 other bodies, consisting of various offices, administrations, institutes and directorates). Similar issues are presented for each of the bodies: status at handover in $201 \mathrm{OI}$ (financial and contractual obligations, as well as pending cases and litigations), the performance of responsibilities in the period 20II-15 (the bodies' scopes of activities, organisation charts including the number of staff, settled cases and reports per organisational unit for the period 2OII-I5), activities in progress and open issues with proposed solutions (prepared laws and bylaws, strategies and other documents, the status of projects in progress, pending cases and litigations, the State Audit Office's recommendations not carried out and substantiated inspection measures not complied with, as well as financial and contractual obligations) and other notes and explanations (web links, etc.).

Most of the report data should have been included in the annual reports of the ministries and government bodies. The report data should have been published long ago in the regular annual reports of the government bodies. These reports should have contained overviews of operations of the ministries and their budgetary users, as well as a consolidated report on revenues and expenditures and balance sheets. The consolidation of key information from such annual reports would show that most of the data presented in the Report are actually redundant. Let us remind that a large portion of

\footnotetext{
${ }^{1}$ The Report on the Work of the Government of the Republic of Croatia during the Term of Office of the Prime Minister Jadranka Kosor for the period July 2009-December 201 had I,267 pages
} 
the Report data has already been made publicly available, e.g. the prepared laws and bylaws, strategies and other documents, the ministries' organisation charts and responsibility assignment matrices. This Report should include only basic (aggregate) indicators enabling the performance assessment of Croatia's Government Programme measures in the 2OII-I5 term of office. The Report should also include a summary and a statistical annex with key fiscal indicators. This would facilitate public access to the Government's activities and enable the assessment of its work.

Major parts of the Report. The most interesting and informative are parts of the reports of the: Ministry of Finance (dealing with debt, borrowing, guarantees, technical budget reforms, fiscal impact assessment and strategic planning, local units' borrowing and non-profit organisations' operations), Ministry of Economy (only a small fraction, dealing with the plan for the implementation of orders and recommendations, mainly regarding shipyard restructuring), Ministry of Health (the part which contains an overview of healthcare institution rescues by type of payment, debt arrears and data on the performance of the Croatian Health Insurance Fund) and of the State Office for State Property Management.

Incomplete information on public debt. Despite the relatively detailed information provided by the Ministry of Finance, it is not clear why the data on debt and guarantees do not include the last quarter of 2015, when substantial direct and indirect liabilities were incurred. Specifically, at its session on December IO, 2015, the outgoing Government took decisions on borrowing and issuing guarantees worth about HRK I.7bn at extremely short notice (in as little as 4 minutes ${ }^{2}$. The Government issued a „Christmas“ bond and adopted a Decision on Initiating a Procedure for an Agreement on Providing a Guarantee to the Croatian Motorways Company (HAC). Moreover, decisions were taken to grant approvals for borrowing to the City of Zagreb and Municipality of Primošten. ${ }^{3}$

A poor and messy layout. The Report is badly laid out and uncoordinated. There is no colour consistency in the tables and graphs presented in the text, and some tables are copy-pasted from other documents and therefore hard to read. Table headings are not followed by the tables on one and the same page, which ranks the Report in a category of a poorly written seminar paper. The sloppiness of the Report is also illustrated by the fact that chapter headings are often written at page bottoms (e.g. pages I07-IO9), while the chapters themselves begin on next pages. So, it is reasonable to ask whether the final version of the Report has ever been proofread, edited and reviewed.

No passing grade for the Report. Besides being mandatory, the preparation of such an important document is necessary and desirable. However, an analysis of the form and content of the Report shows that it deserves no passing grade. Some parts of it, relating to certain government bodies, are too extensive, dispersing the focus and making it impossible to assess the Government's work during the term of office. The Report should briefly present the results of the Government's programme implementation and reforms carried out on the revenue and expenditure sides.

A new Government should have the current Act on the Power Transfer Procedure complemented by a rulebook for a more detailed regulation of the scope and format of the Report. Moreover, it would have been helpful if the technical Government had prepared a summary report on the financial activities (and their consequences) undertaken from the election announcement date to the handover of power to a new Government.

\footnotetext{
${ }^{2}$ See: https://www.youtube.com/watch?v=xFcBudnoZNI.

3 The Government should have prepared a detailed report on these transactions to convince the public and parliamentary parties that it had not violated Article 5 of the Act on the Power Transfer Procedure (OG 94/O4, I7/O7 and 9I/IO) which stipulates that, as from the date of announcement of elections, the Government may not enter into any contracts of significant value.
} 